\title{
Adrenomedullin expression in the mouse mammary gland: evidence for the mature form in milk
}

\section{G D Jahnke, M-J Miller ${ }^{1}$, A Martínez ${ }^{1}$, L Montuenga ${ }^{1}$ and F Cuttitta ${ }^{1}$}

Reproductive Toxicology Workgroup, Laboratory of Toxicology, National Institute of Environmental Health Sciences, Research Triangle Park, North Carolina 27709, USA

${ }^{1}$ Biomarkers and Prevention Research Branch, Division of Cancer Prevention and Control, National Cancer Institute, National Institutes of Health, Rockville, Maryland 20850-3300, USA

(Requests for offprints should be addressed to G D Jahnke, Reproductive Toxicology Group, Building 101, MD B3-05, National Institute of Environmental Health Sciences, Research Triangle Park, North Carolina 27709, USA)

\begin{abstract}
Adrenomedullin (AM) is a recently identified amidated peptide produced by a variety of tissue types. We have investigated the involvement of AM and its receptor (AM-R) in developing mouse mammary glands and have examined what influence ovarian hormones have on AM and AM-R expression in this system. Tissues from ductal morphogenesis, virgin adult, pregnancy, and lactation stages were assessed for AM and AM-R by molecular, biochemical and immunohistochemical techniques. Results from these studies indicated that messenger RNA for AM and AM-R and immunoreactivity for AM were expressed in the luminal epithelium of small and large ducts and in terminal end buds. Immunoreactive AM was identified as a cytoplasm component of ductal cells,
\end{abstract}

with some cells also having nuclear staining. Western blot analysis of mammary gland tissues yielded two molecular mass species $\left(M_{\mathrm{r}} 14000\right.$ and 18 500) of AM immunoreactivity in the mammary gland for the above developmental stages, consistent with processed intermediate and prohormone forms respectively. Ovariectomy alone or followed by hormonal treatments did not alter the expression pattern for these two proteins. By Western blot, the fully processed AM form $\left(M_{\mathrm{r}} 6000\right)$ was identified in milk extracts from lactating glands. These data suggest a potential role for AM and its receptor in the maintenance of mammary gland homeostasis and suggests a potential role for AM in development of the newborn.

Fournal of Molecular Endocrinology (1997) 19, 279-289

\section{INTRODUCTION}

Adrenomedullin (AM) is a potent hypotensive 52 amino acid peptide originally isolated from human pheochromocytoma (Kitamura et al. 1993a). It is synthesized as a 185 amino acid precursor which is processed by consecutive enzymatic steps into a 6000 molecular mass bioactive peptide (Kitamura et al. 1993b, Sugo et al. 1994). AM production has been characterized in a wide spectrum of tissues, including the cardiovascular (Sakata et al. 1993), nervous (Ueta et al. 1995, Wang et al. 1995, Satoh et al. 1996), respiratory (Martínez et al. 1995b), endocrine (Martínez et al. 1996, Satoh et al. 1996), renal (Jougaski et al. 1994), and digestive systems (Washimine et al. 1995). AM mRNA expression is enhanced by inflammatory response elements (interleukin-1 and tumor necrosis factor) and the peptide is markedly up-regulated in the circulation following endotoxin (lipopolysaccharide) challenge or bacterial sepsis (Sugo et al. 1995, Hirata et al. 1996). A variety of biological effects have been assigned to AM which include: vasodilator (Kitamura et al. 1993a, Eguchi et al. 1994, Lippton et al. 1994, Nossaman et al. 1995), bronchodilator (Kanazawa et al. 1994), neurotransmitter (Allen \& Ferguson 1996), anti-secretagogue (Samson et al. 1995, Yamaguchi et al. 1995, Martínez et al. 1996), and a promoter of cell proliferation (Miller et al. 1996, Withers et al. 1996). AM has been shown to mediate these bioactive effects through a seventransmembrane G-protein associated receptor which acts through the activation of adenyl cyclase (Ishizaka et al. 1994, Kapas et al. 1995). 
In the mammary gland from nulliparous mice, growth and maintenance of ductal epithelium is primarily dependent upon the ovarian steroids, estrogen and progesterone; following conception, ductal branching, alveolarization and lactation allow for terminal differentiation of the gland (Nandi 1958). Several of these mammary gland processes have been shown to be modulated by cAMP levels (Rillema 1976, Silberstein et al. 1984). In light of previous reports suggesting a role for AM in hormone secretion, cell growth and cAMP regulation, we investigated the involvement of $\mathrm{AM}$ and its receptor (AM-R) in the mouse mammary gland. In addition, we examined whether this ligand/receptor relationship was influenced in a hormone-dependent and developmentally-specific manner. Both molecular and biochemical studies were performed on the mammary glands of mice at various stages of development: peripubertal and mature virgin mice and pregnant and lactating adult mice. Additionally, we evaluated ovariectomized adult virgin mice for $\mathrm{AM}$ and AM-R expression before and after estrogen and/or progesterone treatment.

\section{MATERIALS AND METHODS}

\section{Animals}

Female mice (CD-1 (Crl:CD-1(ICR)), Charles River Breeding Laboratories, Raleigh, NC, USA) were housed under controlled temperature $\left(22^{\circ} \mathrm{C}\right)$, with a ratio of $12 \mathrm{~h}$ light: $12 \mathrm{~h}$ darkness and humidity $(50 \%)$, and were given NIH31 rodent diet and water and allowed to feed ad libitum. All animal experimental protocols were approved by the NIEHS Animal Care and Use Committee. Animals were anesthetized with ketamine/xylazine and killed by cervical dislocation. For RNA or protein extraction, tissues were rapidly removed under aseptic conditions, frozen in liquid $\mathrm{N}_{2}$ and then stored at $-80{ }^{\circ} \mathrm{C}$. Lymph nodes were dissected from the mammary tissue before further tissue extraction.

\section{Hormone treatments}

Female virgin mice were ovariectomized by the breeder at maturity ( 8 weeks) and then housed at NIEHS. At 20 weeks of age, animals were divided into four treatment groups of six each and received a daily injection $(0 \cdot 1 \%$ body weight, s.c.) of corn oil (control group), 17- $\beta$ estradiol (1 $\mu \mathrm{g} /$ day), progesterone $(1 \mathrm{mg} /$ day $)$ or a mixture of both estradiol $(1 \mu \mathrm{g} /$ day $)$ and progesterone $(1 \mathrm{mg} /$ day $)$ for a period of 7 days before killing on day 8 (Haslam et al. 1992). Estradiol and progesterone were obtained from Sigma Chemical Company (St Louis, MO, USA). The tissues obtained for paraffin embedding were fixed in $10 \%$ neutral buffered formalin for $18-24 \mathrm{~h}$. Whole mounts of mammary gland tissue were prepared as previously described (Russo et al. 1989).

\section{Cell culture and RNA extraction}

NIH-H720, a lung carcinoid cell line, was used as a positive control (NCI-Navy Oncology Medical Branch). Cells were grown in serum-free, hormonefree medium as previously described (Martínez et al. 1995a). mRNA was extracted from fresh cell pellets using the Trizol reagent (Life Technologies, Gaithersburg, MD, USA) following the manufacturer's procedure.

Frozen tissues were homogenized with a Polytron homogenizer (setting 8, 30 s) in TriReagent (Millipore, Bedford, MA, USA) following the manufacturer's instructions. The amount of RNA isolated was determined spectrophotometrically.

\section{RT-PCR and Southern blot analysis}

Poly $\mathrm{A}^{+}$mRNA from normal human lung was purchased from Clontech (Palo Alto, CA, USA). Reverse transcription polymerase chain reaction (RT-PCR), and Southern blot were carried out as previously described (Martínez et al. 1996). A set of primers that recognizes the most conserved regions of the AM gene was designed and is shown in Table 1. $\beta-2$ microglobin, a protein component of the cell membrane, was used to verify the presence of RNA in the RT-PCR samples (data not shown). PCR for AM and $\beta-2$ microglobin was performed at $94{ }^{\circ} \mathrm{C}$ for $15 \mathrm{~s}, 55^{\circ} \mathrm{C}$ for $15 \mathrm{~s}, 72{ }^{\circ} \mathrm{C}$ for $1 \mathrm{~min}$ for 35 cycles. The same PCR conditions were used for AM-R except that the annealing temperature was $61{ }^{\circ} \mathrm{C}$. All RT-PCR primers and the probes are listed in Table 1.

One percent agarose gels were run at $100 \mathrm{~V}$ for approximately $2.5 \mathrm{~h}$, then denatured in $1.5 \mathrm{M}$ $\mathrm{NaCl} / 0.6 \mathrm{M} \mathrm{NaOH}(2 \times 30 \mathrm{~min})$ and $1.5 \mathrm{M} \mathrm{NaCl} /$ $2 \mathrm{M}$ Tris $(2 \times 30 \mathrm{~min})$ and blotted overnight onto a $0.2 \mathrm{~mm}$ nitrocellulose filter in $20 \times \mathrm{SSC}$ by capillary flow transfer. The filter was cross-linked at $80{ }^{\circ} \mathrm{C}$ under vacuum and incubated in hybridization buffer. The antisense nested probes for AM or AM-R were ${ }^{32} \mathrm{P}$-endlabeled by standard procedures and hybridization with the probe was carried out overnight at $42{ }^{\circ} \mathrm{C}$. Room temperature stringency washing was in $5 \times \mathrm{SSC} / 0 \cdot 1 \% \mathrm{SDS}$ and $1 \times \mathrm{SSC} /$ $0 \cdot 1 \%$ SDS. Filters were air dried and autoradiographed on Kodak XAR5 film. 
TABLE 1. Sequences of the oligonucleotides synthesized for this study

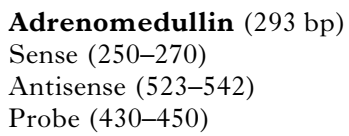

Adrenomedullin (293 bp)

Antisense (523-542)

Probe (430-450)

5'-AAG-AAG-TGG-AAT-AAG-TGG-GCT-3'
5'-TGT-GAA-CTG-GTA-GAT-CTG-GT-3'
5'-TCT-GGC-GGT-AGC-GCT-TGA-CTC-3'

\author{
Adrenomedullin receptor $(471 \mathrm{bp})$ \\ Sense (476-497) \\ Antisense (923-946) \\ 5'-AGC-GCC-ACC-AGC-ACC-GAA-TAC-G-3' \\ 5'-AGA-GGA-TGG-GGT-TGG-CGA-CAC-AGT-3' \\ Probe (788-811) \\ 5'-GGT-AGG-GCA-GCC-AGC-AGA-TGA-CAA-3' \\ B2 Microglobulin ${ }^{\mathrm{a}}(217 \mathrm{bp})$ \\ Sense (235-256) \\ 5'-GAC-TGG-TCT-TTC-TAT-ATC-CTG-G-3' \\ Antisense (432-452)
}

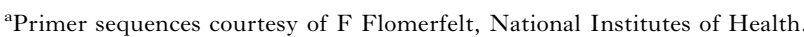

\section{Western blotting}

Whole cell lysates of tumor cell line NIH-H720 were generated following a slightly modified protocol from that previously reported (Martínez et al. 1995b). In summary, cells were harvested $48 \mathrm{~h}$ after their last feeding, washed three times in cold PBS and pelleted by centrifugation (1000 r.p.m. for $10 \mathrm{~min}$ at $\left.4{ }^{\circ} \mathrm{C}\right)$. The pellet $\left(5 \times 10^{7}\right.$ cells $)$ was re-suspended in $1 \mathrm{ml}$ cold PBS containing $1 \mathrm{~mm}$ final concentration of each of the following protease inhibitors: pefabloc (Centerchem Inc., Stanford, CT, USA), bestatin and phosphoramidon (Sigma Chemical Company). The cell suspension was maintained at $4{ }^{\circ} \mathrm{C}$ at all times, then homogenized, sonicated, clarified by ultracentrifugation and the final protein concentration determined (BioRad Laboratories, Richmond, CA, USA). Normal tissue extracts were obtained from Clontech. BALB/c mouse milk was acid-extracted with $2 \mathrm{~N}$ glacial acetic acid and boiled for $10 \mathrm{~min}$, followed by centrifugation and collection of the supernatant. Protease inhibitors (see above) were added to the supernatant.

Cell lysates and tissue extracts $(35 \mathrm{mg}$ protein/ well) were electrophoretically fractionated on a $10-$ $20 \%$ Tricine gel (Novex, San Diego, CA, USA) at $100 \mathrm{~V}$ for $2 \mathrm{~h}$ under reducing ( $\beta$-mercaptoethanol) and non-reducing conditions. A total of $2 \mathrm{ng}$ synthetic AM (Phoenix Biochemicals, Phoenix, AZ, USA) were added to a separate well as a positive control standard. Transfer blotting was accomplished in the same apparatus equipped with a titanium plate electrode insert and proteins affixed to a polyvinyldifluoride membrane (Immobilon PVDF, Millipore) at $30 \mathrm{~V}$ for $2 \mathrm{~h}$. Membrane was blocked overnight in $1 \%$ BSA-PBS, incubated for $1 \mathrm{~h}$ in 1:1000 dilution of rabbit anti-P072 (bleed \#2343), washed $3 \times$ in PBS, exposed to $1 \times 10^{6}$ c.p.m. ${ }^{125} \mathrm{I}$-Protein $\mathrm{A}$ for $1 \mathrm{~h}$ at $28^{\circ} \mathrm{C}$, washed $6 \times$ in PBS, dried and autoradiographed overnight at $-80{ }^{\circ} \mathrm{C}$ on Kodak XAR5 film. Specificity control consisted of a duplicate membrane incubated in diluted antiserum which had been preabsorbed with $10 \mathrm{nmol}$ P072 antigen (Martínez et al. 1995b) per ml diluted antiserum.

\section{In situ RT-PCR}

In order to determine tissue expression sites for AM, a direct method for in situ amplification of mRNA (Martínez et al. 1995a) was performed in a Hybaid OmniSlide System thermocycler (National Labnet Company, Woodbridge, NJ, USA). After dewaxing, the sections were subjected to permeabilization with $10 \mathrm{mg} / \mathrm{ml}$ proteinase K (Sigma Chemical Company) for $15 \mathrm{~min}$ at $37^{\circ} \mathrm{C}$. RT was performed using the SuperScript Preamplification System (Gibco BRL, Gaithersburg, MD, USA) prior to the PCR. The Taq polymerase was blocked with a specific monoclonal antibody (TaqStart, Clontech) before being added to the PCR mixture in order to obtain a synchronous 'hot start' for all the slides. The PCR mixture contained $2.5 \mathrm{~mm}$ $\mathrm{MgCl}_{2}, 200 \mathrm{~mm}$ dNTPs, $100 \mathrm{~mm}$ digoxigenin-dUTP (Boehringer Mannheim, Indianapolis, IN, USA), $1 \mathrm{ng}$ of each primer, $50 \mathrm{~mm} \mathrm{KCl,} 10 \mathrm{~mm}$ Tris- $\mathrm{HCl}$, pH 8.3. Products were located after PCR amplification for 20 cycles (annealing temperature, $55^{\circ} \mathrm{C}$ ) using a Digoxigenin Detection Kit (Boehringer Mannheim, following manufacturer's instructions). Negative amplification controls included the omission of reverse transcriptase and the substitution of the primers by water in the PCR mixture.

\section{In situ hybridization}

Detection of the AM-R mRNA was performed using in situ hybridization as previously described 
(Martínez et al. 1996). The full-length cDNA was ligated into the expression vector pcDNA1 (Kapas et al. 1995) and used to generate riboprobes. The plasmid was linearized with EcoRV and BamHI and was used as a template to synthesize digoxigeninlabeled sense and anti-sense RNA transcripts. Hybridization was performed in a moist chamber at $46{ }^{\circ} \mathrm{C}$ for $20 \mathrm{~h}$ in a $20 \mathrm{ml}$ volume containing $2.5 \mathrm{ng}$ probe $/ \mathrm{ml}$. After stringency washes, visualization of digoxigenin was performed using a detection kit (Boehringer Mannheim). Controls included the use of the sense probe and digestion with RNase before hybridization.

\section{Immunohistochemistry}

An avidin-biotin-peroxidase complex method was performed in paraffin sections as previously reported (Martínez et al. 1995b, 1996), except that phosphate-buffered saline was replaced with $50 \mathrm{~mm}$ Tris, $0 \cdot 1 \%$ bovine serum albumin, $0 \cdot 9 \% \mathrm{NaCl}$. The polyclonal antibody specific to AM was used for immunohistochemistry at a concentration 1:1000. Negative controls included substitution of the primary antibody by pre-immune serum from the same rabbit and solid phase preabsorption of the antibody overnight at $4{ }^{\circ} \mathrm{C}$ with $10 \mathrm{nmol} / \mathrm{ml}$ synthetic peptide.

\section{RESULTS}

\section{$A M$ and AM-R expression in mouse mammary tissue extracts}

The presence of mRNA for AM and AM-R was determined by RT-PCR in mouse mammary glands at different developmental stages and after estradiol or progesterone treatment of virgin, ovariectomized mice. Oligonucleotide probes specific to AM or AM-R cDNA (Table 1) were hybridized to Southern transferred amplified products (Fig. 1A and B). All samples expressed AM and AM-R by either this method or by ethidium bromide staining of the gel purified amplified product (data not shown); the control ovariectomized group expressed AM-R RNA by the latter method. NIH-H720 human lung carcinoid cell-line and rat lung tissue (Martínez et al. 1995b) were used as positive controls. RTPCR of the samples with $\beta-2$ microglobin primers was used to verify the presence of intact RNA (data not shown).

Western blotting of mammary tissue extracts using a previously characterized (Martínez et al. 1995b) AM antibody to the C-terminal region of the protein (P072, amino acids 116-146) revealed immunoreactive bands at $M_{\mathrm{r}} 18500$ and 14000 for all tissue extracts examined (Fig. 1C). The former size is consistent with unprocessed AM precursor and the latter size with an intermediate form. The $M_{\mathrm{r}} 6000$ form of AM was not evident in any of the samples tested, but was present in the Western blot of synthetic AM. No immunoreactive bands were evident by Western blotting using antibody preabsorbed with the synthetic P072 (Fig. 1D).

\section{AM immunoreactivity and localization of mRNA for AM and AM-R following hormone treatments}

Whole mounts of the ovariectomized mammary gland after hormone treatments (Fig. 2A-D) showed changes in duct size, branching and terminal endbud formation. Estradiol or estradiol plus progesterone treatments resulted in terminal endbud formation within the gland; progesterone or estradiol plus progesterone treatments resulted in increased ductal branching and increased duct diameter. AM and AM-R specific gene expression was localized in mammary tissues by in situ RT-PCR and in situ hybridization respectively. In all treatment groups, including vehicle control, AM (data not shown) and AM-R mRNAs (Fig. 2E-H) were found in mammary epithelial cells: luminal cells of ducts and alveoli, myoepithelial cells and cells comprising the terminal endbud. Immunoreactivity for AM (Fig. 2I-L) paralleled localization of AM mRNA expression. Periductal fibroblasts were apparently negative for AM mRNA and protein, but positive for AM-R mRNA (AM protein, Fig. 2I-L; AM-R mRNA, Fig. 2E-H).

\section{Localization of AM and AM-R during mammary gland development}

Immunostaining for AM in the cells of the ductal epithelium was observed not only in the cytoplasm but, in a high proportion of cells, also in the nucleus (Figs 2L and 3A). Cytoplasmic staining tended to be concentrated in the apical region of the cell. Positive staining of the nucleus and cytoplasm was abrogated by preabsorption of the AM antibody with synthetic AM (Fig. 3B). Luminal epithelial cells and periductal and fat pad fibroblasts were positive for AM-R mRNA by hybridization to the AM-R antisense probe (Fig. 3C) and negative by hybridization to the sense probe (Fig. 3D). Consistent results were observed for AM and AM-R mRNA and AM immunoreactivity in 31 -day-old virgin, 15-month-old virgin, as well as 14-day pregnant and 4-day post weaning stages of 
A

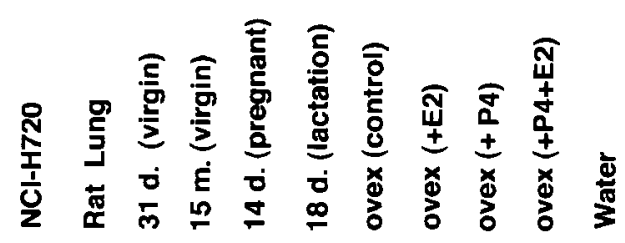

B

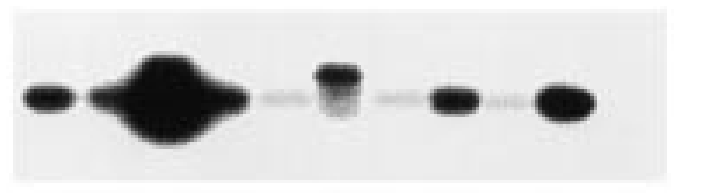

$-293 \mathrm{bp}$

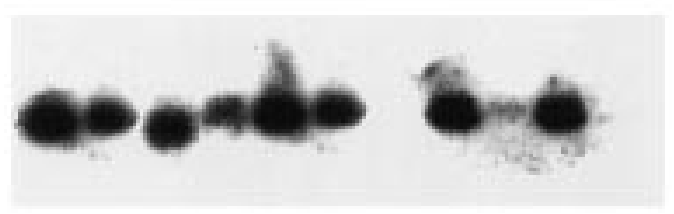

$-471 \mathrm{bp}$
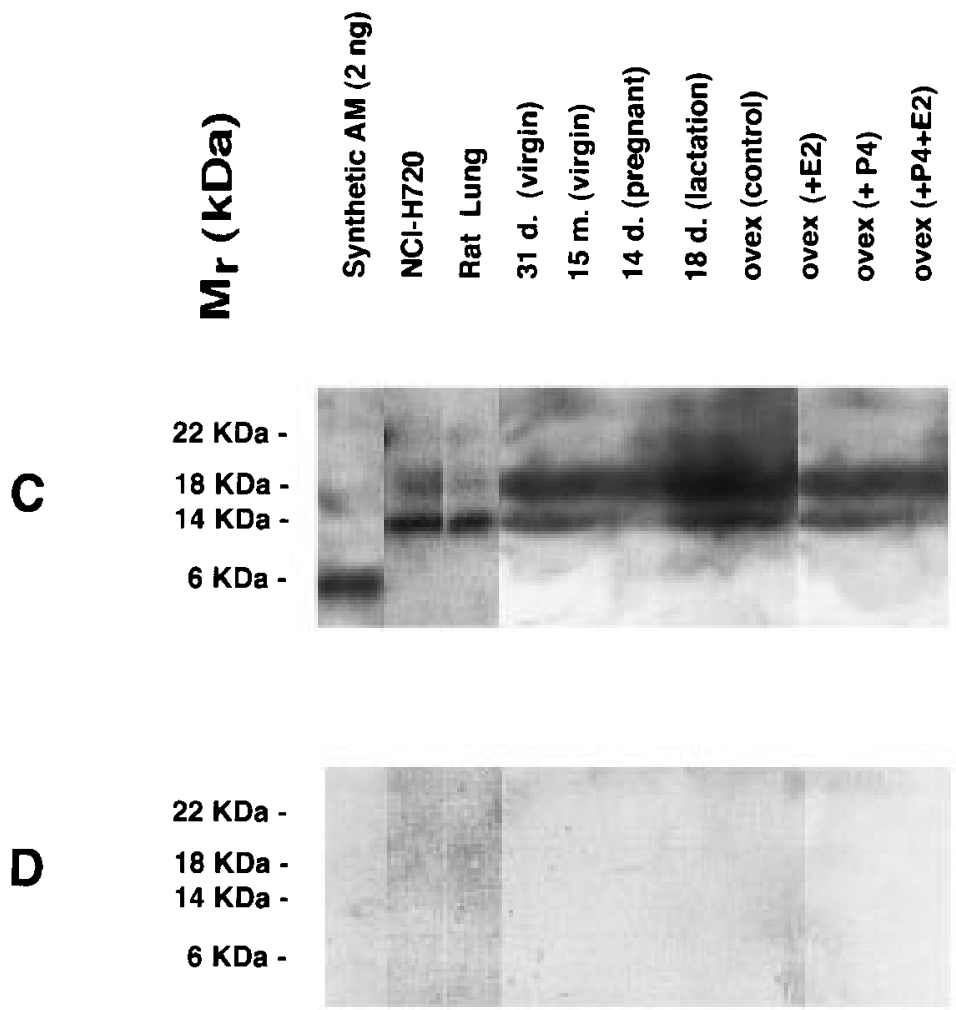

FIGURE 1. Southern blot for AM (A) and AM-R (B) of PCR-amplified cDNA and corresponding Western blot for AM $(\mathrm{C})$ in mammary gland tissues. AM antibody preabsorbed with synthetic P072 peptide (D). NCI-H720: human carcinoid cell line; rat lung; mouse mammary gland from 31-day-old virgin, 15-month-old virgin; day 14 of pregnancy and day 18 of lactation. Ovex: adult virgin mice 3 months post ovariectomy treatment for 7 days with: Control=corn oil; E2=17- $\beta$ estradiol; $\mathrm{P} 4=$ progesterone. Tissues were collected on day $8 . \mathrm{d}=$ day; $\mathrm{m}=$ month; ovex $=$ ovariectomized; Water $=$ negative amplification control. 

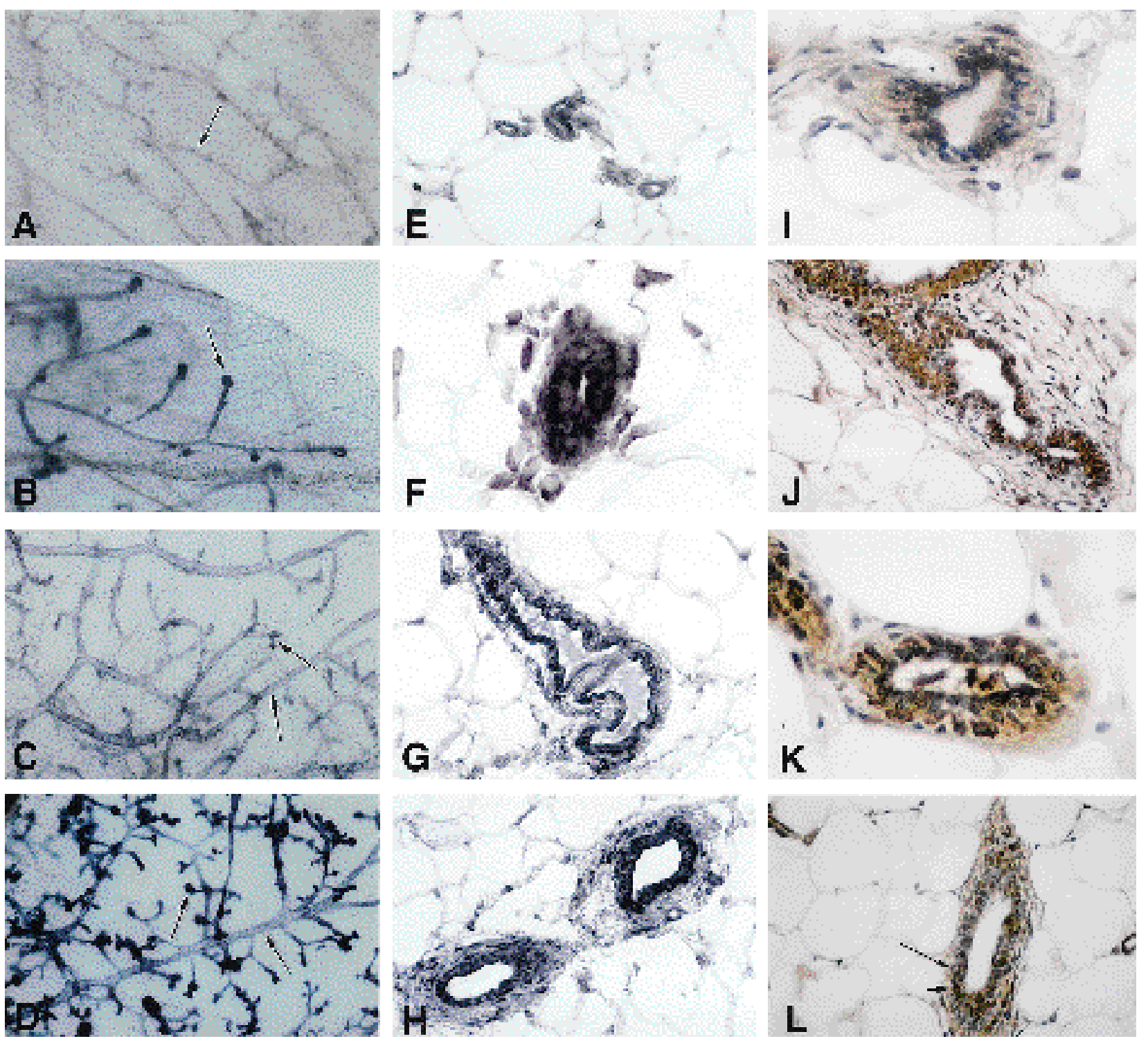

FIGURE 2. Distribution of AM and AM-R in mammary glands from hormone-treated mice, 3 months after ovariectomy. Seven day treatment with corn oil (A, E, I), estradiol (B, F, J), progesterone $(C, G, K)$, or estradiol + progesterone $(\mathrm{D}, \mathrm{H}, \mathrm{L})$. Toluidine blue stained whole mounts (A-D). Arrows in A-D indicate ductal and endbud structures within the fat pad. In situ hybridization with AM-R antisense probe (E-H). Immunohistochemical staining with AM polyclonal antibody (I-L). Note in $\mathrm{L}$ the presence of epithelial cells with either negative (large arrow) or positive (small arrow) nuclear staining. Magnification: A-D, × 16; E, G, H, J, L, × 193; $\mathrm{F}, \mathrm{I}, \mathrm{K}, \times 387$.

development (Fig. 4A-D, not all data shown). Periductal and fat pad fibroblasts were positive for mRNA to AM-R (Fig. 4E), but were immunonegative for AM. The most striking positive staining for $\mathrm{AM}$ and $\mathrm{AM}-\mathrm{R}$ was obtained during lactation (Fig. $3 \mathrm{~A}-\mathrm{D})$; luminal cells and milk within the ducts were positive for AM immunoreactivity.

\section{Localization of mature AM in mouse milk}

Since milk within the ducts was immunoreactive for AM (Fig. 3A), Western blot detection of AM was carried out on mouse milk (Fig. 5). Mouse milk showed evidence of three AM forms: the fully processed AM form $\left(M_{\mathrm{r}}\right.$ 6000), an intermediate 

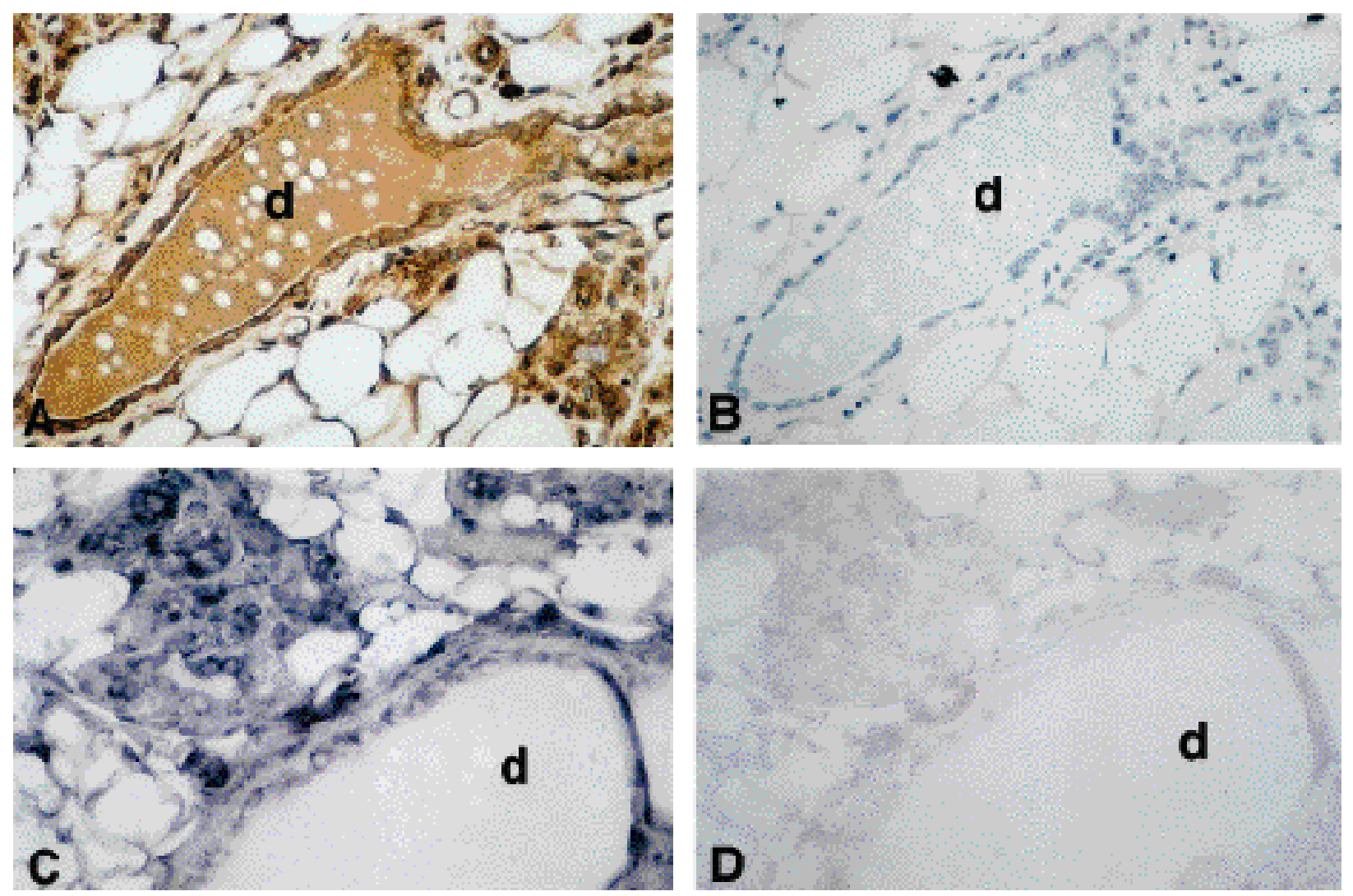

FIGURE 3. Immunohistochemical localization of AM and in situ hybridization for AM-R in the lactating mammary gland. (A) Positive localization for AM at day 18 of lactation. (B) Staining of a serial tissue section with antibody to AM preabsorbed with synthetic P072. (C) In situ hybridization for AM-R with the antisense probe. (D) Negative control using AM-R sense probe in a serial tissue section. d=ductal lumen. Magnification: A-D, $\times 239$.

form ( $\left.M_{\mathrm{r}} 14000\right)$, and unprocessed, prohormone form $\left(M_{\mathrm{r}} 18500\right)$. Under reducing conditions, all bands were greater in intensity. No bands were evident with antibody preabsorbed with the synthetic P072 antigen (Fig. 5B).

\section{DISCUSSION}

Prior molecular studies on AM and AM-R have demonstrated message expression in a variety of tissues including the adrenal gland, heart, lung, kidney (Kitamura et al. 1993a, Sugo et al. 1995, Martínez et al. 1995b) and pancreas (Martínez et al. 1995b). Our identification of AM and AM-R in the mouse mammary gland is another example of the ubiquity of this peptide and its receptor. Evaluation of ductal epithelium by in situ PCR showed AM mRNA in the same cell type that stained a serial section positive for the peptide by immunohistochemistry. In situ hybridization analysis for AM-R message also demonstrated epithelial expression of the receptor, suggesting an autocrine pathway within this cell type. Interestingly, periductal fibroblasts were shown to have AM-R message, but lacked AM, implying a paracrine mode of action associated with their cellular physiology.

The presence of mRNA and immunoreactivity for AM in epithelial cells, but not in the periductal and fat pad fibroblasts, and the presence of mRNA for AM-R in both cell populations suggests that $\mathrm{AM}$ is involved in mesenchymal-epithelial interactions within the mammary gland. Communication of the mammary mesenchyme (periductal fibroblasts) with the epithelium is essential for mammary growth and development from embryonic through adult stages (reviewed in Cunha \& Hom 1996). Parallels of our findings have been seen for growth factors such as transforming growth factor- $\alpha$ / epidermal growth factor (EGF) receptor (Snedeker et al. 1991) or keratinocyte growth factor (Cunha \& Hom 1996). Further investigations could utilize the cleared mammary fat pad model and neutralizing antibodies or peptide antagonists to AM or AM-R 

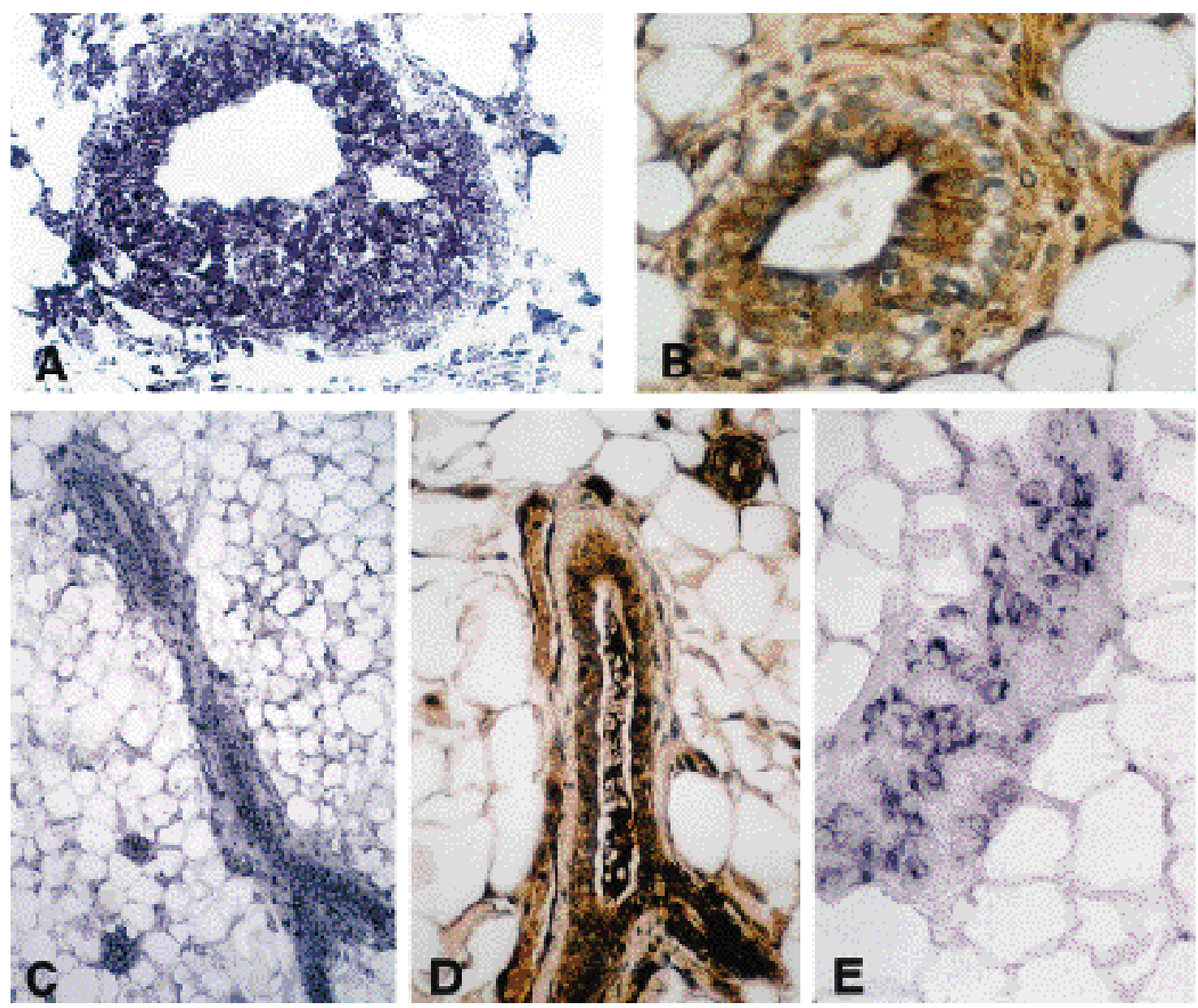

FIGURE 4. In situ distribution of AM and AM-R in the virgin mouse mammary gland. In situ RT-PCR (A) and immunohistochemistry (B) for AM in the terminal endbud from a 31-day-old mouse. In situ hybridization for AM-R (C) and immunohistochemistry for AM (D) in a 15-month-old virgin mouse. Positive staining for AM-R in fibroblasts from C (E). Magnification: A and B, $\times 598 ; \mathrm{C}, \times 134 ; \mathrm{D}$ and $\mathrm{E}, \times 260$.

to determine the role of these factors in the growth and development of the mammary gland.

It has been previously shown by radioimmunoassay quantitation and immunohistochemical detection that AM is ubiquitously expressed in all the major organs of several mammalian species (Kitamura et al. 1993a, Sugo et al. 1995, Martínez et al. 1995b, 1996). We have used a concomitant approach of immunohistochemical and in situ RT-PCR to localize AM expression in mouse mammary glands. By Western blot analysis of the immunoreactive tissue products, AM-like activity was shown to be comprised of two molecular mass species (18 500 and 14000$)$ in all developmental stages examined. Three species were identified by western analysis of acid-extracted mouse milk: $M_{\mathrm{r}}$ 18 500, 14000 , and 6000, the bioactive AM form.
However, Western analysis of the mammary tissue at lactation stage did not yield an immunoreactive band at 6000 . Physiological reasons to be considered for this apparent discrepancy are the rapid cleavage and release of AM into lumenal fluid (Miller et al. 1996) and the heterogeneity of the mammary tissue. Other investigators have reported similar discrepancies in the study of EGF processing within the mammary gland. Although EGF is found in milk, they were unable to detect the mature peptide $\left(M_{\mathrm{r}}\right.$ $6000)$ by standard Western blotting or immunoprecipitation of radioactive protein (Brown et al. 1989) from mammary tissue.

Several studies have now shown that AM can function as a growth regulator in both normal and malignant cells (Chini et al. 1995, Kano et al. 1996, Miller et al. 1996, Withers et al. 1996). In vitro 


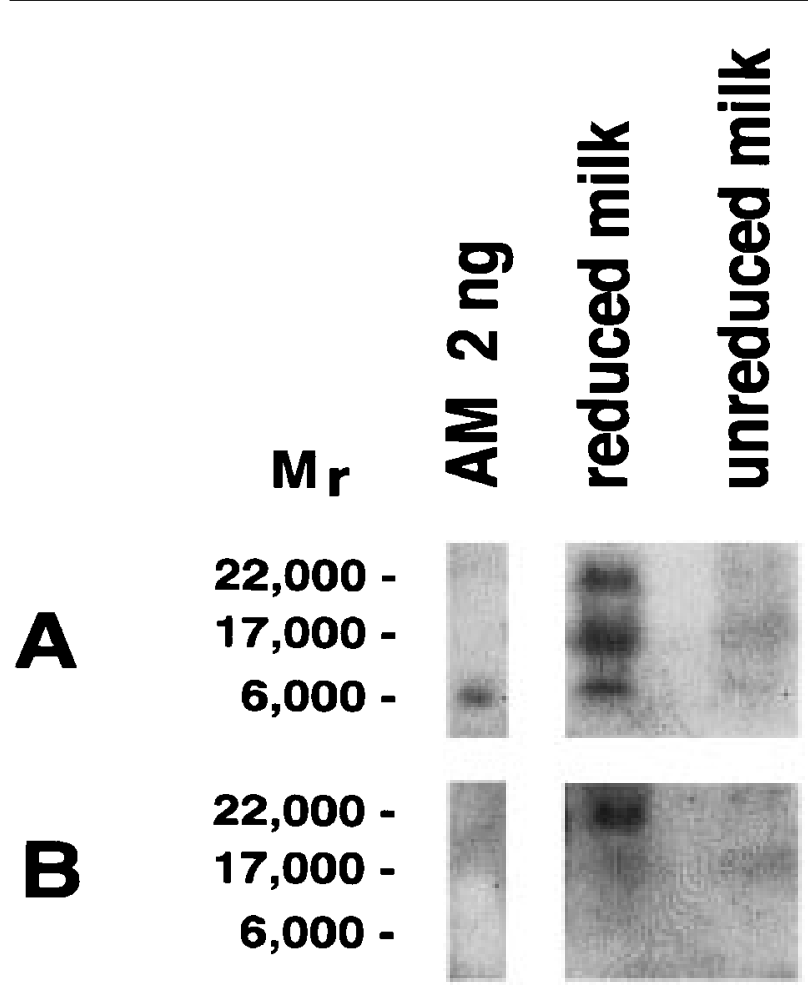

FIGURE 5. Western blot with antibody to AM of mouse milk extract under reducing and non-reducing conditions (A) and with antibody preabsorbed to synthetic P072 peptide (B).

assessment has demonstrated the ability of AM to mediate either a proliferative or suppressive effect on growth, depending on the target cell examined (Kano et al. 1996, Miller et al. 1996). Since AM is an inducer of cAMP, its reputed diametric growth effects are thought to involve the cAMP-dependent protein kinase A isoforms, RI and RII, which are known to regulate cell proliferation and differentiation respectively (Budillon et al. 1995, Miller et al. 1996, Saldise et al. 1996). AM and AM-R expression during the multiple stages of mouse mammary gland development may reflect a duality in growth function, whereby proliferative modes of action are required for elongation or branching of the glands while a growth suppressive status would accompany cellular differentiation during lactation. Such possibilities of AM-mediated growth control in the breast ductal epithelium open several complex issues, for example: 1) What factor/factors regulate AM/AM-R expression? 2) Does AM/ AM-R regulation manifest at the transcriptional or translational level? 3) Is there a hormone dependency to the growth control mechanism? The answers to some or all of these questions will require additional investigative studies beyond the scope of this paper.
The frequent nuclear staining for AM found in our study is difficult to interpret but suggests an involvement of $\mathrm{AM}$ in the biological events taking place in the nuclear compartment. The fact that some but not all of the cells of a given ductal section show their nuclei stained suggests differences between the biological traits of different populations of ductal epithelial cells. Silberstein et al. (1996), have recently reported the same type of differences in the nuclear/cytoplasmic immunolocalization of progesterone receptors in the developing mouse mammary gland. Their work supports the hypothesis that at least two cell types, with different responsiveness to progesterone receptor, are present in the ductal epithelium.

Immunoreactive AM has been previously identified in several luminal epithelia including that of the bronchii (Martínez et al. 1995a) and vaginal tract (Jahnke et al. 1996). The peptide appears to concentrate apically along cell borders and is thought to be released into the luminal space (Martínez et al. 1995a), similar to that observed for the magainins and tracheal antimicrobial peptide (Zasloff 1987, Diamond et al. 1991). We have identified comparable staining characteristics for $\mathrm{AM}$ in ductal epithelium of the mouse mammary gland, suggesting the possibility that AM may play a role in the maternal host defense mechanism. Interestingly, we have identified fully processed $\mathrm{AM}$ in the milk extracts from lactating mice. Transfer of the mature peptide to the neonate may provide a nutritional/developmental role for the peptide in neonatal maturation, similar to what has been shown for EGF. In the lactating mammary gland, EGF is processed from a transmembrane precursor form. The presence of EGF in the milk is essential for the development of the neonatal gastrointestinal tract (Koldovsky et al. 1993).

In conclusion, we have identified AM and AM-R expression in mouse mammary glands using a variety of experimental techniques. AM and AM-R were present in all stages of breast development and were neither affected by the lack of ovarian hormones, nor their presence in the ovariectomized animal. Characterization of the AM protein by Western blot analysis demonstrated immunoreactivity corresponding in size to the AM prohormone and processed intermediate form present in all developmental stages tested. In addition, the fully processed form was identified in acid extracts of mouse milk. AM-R expression was found in the mammary epithelium and fibroblasts of all developmental stages examined. The localization of both AM ligand and receptor to ductal epithelial cells and AM-R without the ligand to the periductal and fat pad fibroblasts suggests possible autocrine 
and paracrine involvement respectively. Further investigations are necessary to determine the involvement of AM and AM-R in ductal homeostasis, growth regulation, pathogen protection, and nutritional supplementation to the neonate.

\section{ACKNOWLEDGEMENTS}

We would like to thank Dr Karen Gray, Department of Obstetrics and Gynecology, United States Uniformed Health Services, Bethesda, MD, USA, for her help in initiating this project.

\section{REFERENCES}

Allen MA \& Ferguson AV 1996 In vitro recordings from area postrema neurons demonstrate responsiveness to adrenomedullin. American Fournal of Physiology $\mathbf{2 7 0}$ R920-R925.

Brown CF, Teng CT, Pentecost BT \& DiAugustine RP 1989 Epidermal growth factor precursor in mouse lactating mammary gland alveolar cells. Molecular Endocrinology 3 1077-1083.

Budillon A, Cereseto A, Kondrashin A, Nesterova M, Merlo G, Clair T \& Cho-Chung YS 1995 Point mutation of the autophosphorylation site or in the nuclear location signal causes protein kinase A RII beta regulatory subunit to lose its ability to revert transformed fibroblasts. Proceedings of the National Academy of Sciences of the USA 92 10634-10638.

Chini EN, Choi E, Grande JP, Burnett JC \& Dousa TP 1995 Adrenomedullin suppresses mitogenesis in rat mesangial cells via cAMP pathway. Biochemical and Biophysical Research Communications 215 868-873.

Cunha GR \& Hom YK 1996 Role of mesenchymal-epithelial interactions in mammary gland development. Fournal of Mammary Gland Biology and Neoplasia 1 21-35.

Diamond G, Zasloff M, Eck H, Brasseur M, Maloy WL \& Bevins CL 1991 Tracheal antimicrobial peptide, a cysteine-rich peptide from mammalian tracheal mucosa: peptide isolation and cloning of a cDNA. Proceedings of the National Academy of Sciences of the USA 88 3952-3956.

Eguchi S, Hirata Y, Iwasaki H, Sato K, Watanabe TX, Inui T, Nakajima K, Sadakibara S \& Marumo F 1994 Structureactivity relationship of adrenomedullin, a novel vasodilatory peptide, in cultured rat vascular smooth muscle cells. Endocrinology 135 2454-2458

Haslam SZ, Counterman LJ \& Nummy KA 1992 EGF receptor regulation in normal mouse mammary gland. Fournal of Cell Physiology 152 553-557.

Hirata Y, Mitaka C, Sato K, Nagura T, Tsunoda Y, Amaha K \& Marumo F 1996 Increased circulating adenomedullin, a novel vasodilatory peptide, in sepsis. Fournal of Endocrinology and Metabolism 81 1449-1453.

Ishizaka Y, Ishizaka Y, Tanaka M, Kitamura K, Kanawa K, Minamino N, Matsuo H \& Eto T 1994 Adrenomedullin stimulates cyclic AMP formation in rat vascular smooth muscle cells. Biochemical and Biophysical Research Communications 200 642-646.

Jahnke G, Martínez A, Miller M-J, Cuttitta F, Mitchell A, Nelson M \& Gray K 1996 Investigation of adrenomedullin expression in the mouse mammary gland and reproductive tract. Keystone Symposia, Breast and Prostate Cancer, Taos, NM (Abstract) 199635.
Jougaski M, Wei C-M, Aarhus LL, Heublein DM, Sandberg SM \& Burnett JC Jr 1994 Renal localization and actions of adrenomedullin: a natriuretic peptide. American fournal of Physiology 268 69-73.

Kanazawa H, Kurihara N, Hirata K, Kudoh S, Kawaguchi T \& Takeda T 1994 Adrenomedullin, a newly discovered hypotensive peptide, is a potent bronchodilator. Biochemical and Biophysical Research Communications 205 251-254.

Kano H, Kohno M, Yashunari K, Yokokawa K, Horio TY, Ikeda M, Minami M, Hanehira T, Takeda T \& Yoshikawa J 1996 Adrenomedullin as a novel antiproliferative factor of vascular smooth muscle cells. Fournal of Hypertension 14 209-213.

Kapas S, Catt KJ \& Clark, AJ 1995 Cloning and expression of cDNA encoding a rat adrenomedullin receptor. Fournal of Biological Chemistry 270 25344-25347.

Kitamura K, Kangawa K, Kawamoto M, Ichiki Y, Nakamura S, Matsuo H \& Eto T 1993a Adrenomedullin: a novel hypotensive peptide isolated from human pheochromocytoma. Biochemical and Biophysical Research Communications 192 553-560.

Kitamura K, Sakata J, Kangawa K, Kojima M, Matsuo H \& Eto T $1993 b$ Cloning and characterization of cDNA encoding a precursor for human adrenomedullin. Biochemical and Biophysical Research Communications 194 720-725.

Koldovsky O, Kong W, Philipps AF \& Rao RK 1993 Studies on milk-borne insulin-like growth factor-1 and 2 (IGF-1 and IGF-2) and epidermal growth factor (EGF) in suckling rats. Endocrine Regulation 27 149-153.

Lippton H, Chang J, Hao Q, Summer W \& Hyman AL 1994 Adrenomedullin dilates the pulmonary vascular bed in vivo. Fournal of Applied Physiology 76 2154-2156.

Martínez A, Miller MJ, Quinn K, Unsworth EJ, Ebina M \& Cuttitta F 1995 a Non-radioactive localization of nucleic acids by direct in situ PCR and in situ RT-PCR in paraffinembedded sections. Fournal of Histochemistry and Cytochemistry 43 739-747.

Martínez A, Miller, MJ, Unsworth, J, Siegfried JM \& Cuttitta F $1995 b$ Expression of adrenomedullin in normal human lung and in pulmonary tumors. Endocrinology 136 4099-4105.

Martínez A, Weaver C, López J, Bhathena SJ, Elsasser TH, Miller M-J, Moody TW, Unsworth EJ \& Cuttitta F 1996 Regulation of insulin secretion and blood glucose metabolism by adrenomedullin. Endocrinology 137 2626-2632.

Miller MJ, Martínez A, Unsworth EJ, Thiele CJ, Moody TW \& Cuttitta F 1996 Adrenomedullin: expression in human tumor cell lines. Its potential role as an autocrine growth factor. Fournal of Biological Chemistry 271 23345-23351.

Nandi S 1958 Hormonal control of mammogenesis and lactogenesis in the $\mathrm{C} 3 \mathrm{H} / \mathrm{He}$ CRGL mouse. Zoology 65 1-127.

Nossaman BF, Feng CJ, Cheng DY, Dewitt BJ, Coy DH, Murphy WA \& Kadowitz PJ 1995 Comparative effects of adrenomedullin, an adrenomedullin analog, and CGRP in the pulmonary vascular bed of the cat and rat. Life Sciences 56 PL63-PL66.

Rillema JA 1976 Cyclic nucleotides, adenylate cyclase, and cyclic AMP phosphodiesterase in mammary glands from pregnant and lactating mice. Proceedings of the Society for Experimental Biology and Medicine 151 748-751.

Russo IH, Tewari M \& Russo J 1989 In Integument and Mammary Glands, p 239. Eds TC Jones, U Mohr \& RD Hunt. Berlin: Springer-Verlag.

Sakata J, Shimokubo T, Kitamura K, Nakamura S, Kangawa K, Matsuo H \& Eto T 1993 Molecular cloning and biological activities of rat adrenomedullin, a hypotensive peptide. Biochemical and Biophysical Research Communications 195 921-927. 
Saldise L, Martínez A, Montuenga LM, Treston A, Springall DR, Polak JM \& Vázquez JJ 1996 Distribution of peptidyl-glycine alpha-amidating mono-oxygenase (PAM) enzymes in normal human lung and in lung epithelial tumors. Fournal of Histochemistry and Cytochemistry 44 3-12.

Samson WK, Murphy T \& Schell DA 1995 A novel vasoactive peptide, adrenomedullin inhibits pituitary adrenocorticotropin release. Endocrinology 136 2349-2352.

Satoh F, Takahashi K, Murakami O, Totsune K, Sone M, Ohneda M, Sasano H \& Mouri T 1996 Immunocytochemical localization of adrenomedullin-like immunoreactivity in the human hypothalamus and the adrenal gland. Neuroscience Letters 203 207-210.

Silberstein GB, Strickland P, Trumpbour V, Coleman S \& Daniel CW 1984 In vivo, cAMP stimulates growth and morphogenesis of mouse mammary ducts. Proceedings of the National Academy of Sciences of the USA 81 4950-4954.

Silberstein GB, Van Horn K, Shyamala G \& Daniel CW 1996 Progesterone receptors in the mouse mammary duct: distribution and developmental regulation. Cell Growth and Differentiation 7 945-952.

Snedeker SM, Brown CF \& DiAugustine RP 1991 Expression and functional properties of transforming growth factor alpha and epidermal growth factor during mouse mammary gland ductal morphogenesis. Proceedings of the National Academy of Sciences of the USA 88 276-280.

Sugo S, Minamino N, Kangawa K, Miyamoto K, Kitamura K, Sakata J, Eto T \& Matsuo H 1994 Endothelial cells actively synthesize and secrete adrenomedullin. Biochemical and Biophysical Research Communications 201 1160-1166.

Sugo S, Minamino N, Shoji H, Kangawa K, Kitamura K, Eto T \& Matsuo H 1995 Interleukin-1, tumor necrosis factor and lipopolysaccharide additively stimulate production of adrenomedullin in vascular smooth muscle cells. Biochemical and Biophysical Research Communications 207 25-32.

Ueta Y, Kitamura K, Isse T, Shibuya I, Kabashima N, Yamamoto S, Kangawa K, Matsuo H, Eto T \& Yamashita H 1995 Adrenomedullin-immunoreactive neurons in the paraventricular and supraoptic nuclei of the rat. Neuroscience Letters 202 37-40.

Wang X, Yue T-L, Barone FC, White RF, Clark RK, Wilette RN, Sulpizio AC, Aiyar NV, Ruffolo RR \& Feuerstein GZ 1995 Discovery of adrenomedullin in rat ischemic cortex and evidence for its role in exacerbating focal brain ischemic damage. Proceedings of the National Academy of Sciences of the USA 92 11480-11484.

Washimine H, Asada Y, Kitamura K, Ichiki Y, Hara S, Yamamoto Y, Kangawa K, Sumiyoshi A \& Eto T 1995 Immunohistochemical identification of adrenomedullin in human, rat, and porcine tissue. Histochemical Cell Biology 103 251-254.

Withers DJ, Coppock HA, Seufferlein T, Smith DM, Bloom SR \& Rozengurt E 1996 Adrenomedullin stimulates DNA synthesis and cell proliferation via elevation of cAMP in Swiss 3T3 cells. FEBS Letters 378 83-87.

Yamaguchi T, Baba K, Doi Y \& Yano K 1995 Effect of adrenomedullin on aldosterone secretion by dispersed rat adrenal zona glomerulosa cells. Life Sciences 56 379-387.

Zasloff M 1987 Magainins, a class of antimicrobial peptides from Xenopus skin: isolation, characterization of two active forms, and partial cDNA sequence of a precursor. Proceedings of the National Academy of Sciences of the USA 84 5449-5453.

RECEIVED 24 February 1997 